\title{
User Innovation and Hacking
}

\author{
Eric von Hippel and Joseph A. Paradiso
}

$\mathrm{n}$ the introduction to this special issue

on hacking, the guest editors describe the true hacker as "an individual who can achieve miracles by appropriating, modifying, or 'kludging' existing resources (devices, hardware, software, or anything within reach) to suit other purposes, often in an ingenious fashion." In this Spotlight article, we explain that a hacker is often a "user" who is reinventing or modifying products to better satisfy his or her own needs.

Research has shown that the products or services that users develop for themselves are also the basis for many new commercial products and services. In other words, the newproduct development process, historically thought to be dominated by manufacturers that design and produce new products for users, is now understood to be a process largely centered upon prototype innovations developed by users-often via hacking-to serve their own needs.

\section{WHO ARE USERS?}

Users, as we define the term, are firms or individual consumers that expect to benefit from using a product or service-or an innovation. In contrast, producers expect to benefit from selling a product or service.

A firm or an individual can have different relationships to different products or innovations. For example, Boeing produces airplanes, but it uses machine tools. If we examine innovations developed by Boeing for the airplanes it sells, Boeing would be a producer-innovator in those cases. But if we consider Boe- ing's innovations in metal-forming machinery for in-house use in building airplanes, we'd categorize those as user-developed innovations and Boeing as a user-innovator in those cases.

\section{PERVASIVE DEVELOPMENT BY USERS}

In the traditional producer-centric model, producers use patents, copyrights, and other protections to prevent imitators from free-riding on their innovation investments. A user's only role is to have needs, which producers then identify and fill by designing and producing new products. This traditional model fits well under some conditions.

However, a growing body of empiri-

\section{Product development}

(hacking) by users isn't rare; it's a major phenomenon

\section{for both industrial and consumer products.}

cal work shows that users are the first to develop many and perhaps most new industrial and consumer products. Both qualitative observations and quantitative research in diverse fields-including oil refining, chemical production, scientific instruments, semiconductor production, and sports equipmentclearly document that users develop many products and services that are later sold by manufacturing firms.

Empirical studies also show that from 10 to almost 40 percent of users develop new products or modify the products they buy (see Table 1). Product development (hacking) by users isn't rare; it's a major phenomenon for both industrial and consumer products.

Why do so many users develop or modify products for their own use? Mass producers tend to follow a strategy of developing products that are designed to meet the needs of a large market segment well enough to induce purchaseand capture significant profits-from many customers. When users' needs are heterogeneous, this strategy of "a few sizes fit all" leaves many users somewhat dissatisfied-and some users seriously dissatisfied-with the commercial products on sale. When users are dissatisfied with what producers offer, they will often innovate for themselves.

Users' ability to innovate is improving, both radically and rapidly. This is resulting from the steadily improving quality of computer software and hardware, the steadily improving design capabilities that these advances make possible, improved access to easy-to-use tools and components for innovation, and access to a steadily richer innovation commons. Users can combine and coordinate their efforts via new communication media.

\section{DEVELOPING}

\section{NOVEL INNOVATIONS}

Users and producers tend to develop different types of innovations, in part because of information asymmetries: users and producers tend to know different things. To succeed at their work, product developers require information about the customer's needs 
and context of use (generated by users) as well as generic solution information (often initially generated by producers specializing in a particular type of solution). Bringing these two types of information together isn't easy. Both solution information and need information are often very "sticky" - that is, it's costly to move information from the site where it was generated to other sites. ${ }^{9,10}$ As a result, users generally have a more accurate and detailed model of their needs than producers have, while producers have a better model of the solution approach in which they specialize than the user has.

When information is sticky, innovators tend to rely largely on information they already have in stock. One consequence of the information asymmetry between users and producers is that users tend to develop innovations that are functionally novel, requiring a great deal of user-need information and use-context information for their development. In contrast, producers tend to develop innovations that improve on well-known needs (for example, doing the same things more quickly, reliably, or precisely) and that require a rich understanding of solution information for their development.

If we extend the information-asymmetry argument one step further, we see that information stickiness implies that information on hand will also differ among individual users and producers. The information assets of a particular user (or producer) will be closest to what's required to develop a particular innovation, so the cost of developing that innovation will be relatively low for that user or producer. The net result is that user-innovation activities will be distributed across many users according to their information endowments. With respect to innovation, one user is by no means a perfect substitute for another.

\section{FREELY REVEALING INNOVATIONS}

The social efficiency of a system in which individual users develop individ-

TABLE 1

Studies of the frequency of user innovation.

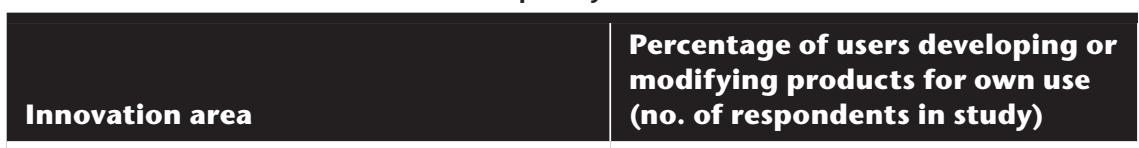

\section{Industrial products}

Printed-circuit CAD software

24.3 (136)

Pipe hanger hardware ${ }^{2}$

$36.0(74)$

Library information systems ${ }^{3}$

$26.0(102)$

Medical surgery equipment ${ }^{4}$

$22.0 \quad(261)$

Apache server software security features ${ }^{5}$

19.1 (131)

\section{Consumer products}

Outdoor consumer products 6

9.8 (153)

"Extreme" sporting equipment ${ }^{7}$

37.8 (157)

Mountain biking equipment ${ }^{8}$

19.2 (291)

ual innovations increases if users somehow reveal what they've developed to others. Producer-innovators partially achieve this when they sell a product or a service on the open market (partially because they reveal the product incorporating the innovation, but often not all the information that others would need to fully understand and replicate it). If user-innovators don't somehow also show what they've done, multiple users with similar needs will have to independently develop similar innovations-a poor use of resources from the viewpoint of social welfare. Empirical research shows that users often do achieve widespread diffusion via an unexpected means: they often "freely reveal" what they've developed. ${ }^{11}$ In other words, the innovator voluntarily gives up all intellectual-property (IP) rights to that information, and all interested parties are given access to it-the information becomes a public good.

The empirical finding that users often freely reveal their innovations has been a major surprise to researchers. On the face of it, if a user-innovator's proprietary information has value to others, you'd think that the user would strive to prevent free diffusion rather than help others get a free ride at private cost. Nonetheless, individual users and user firms-and sometimes producers- often freely reveal detailed information about their innovations.

Innovators often reveal their work freely because it might be the best or the only practical option available to them. ${ }^{12}$ Also, they view IP protections such as patents, trade secrets, and copyrights as having limited practical value. Innovators' active efforts to freely distribute their work gives them significant private benefits. They often find that others then improve or suggest improvements to the innovation, to mutual benefit. ${ }^{13}$ These users also might benefit from enhanced reputation, positive network effects due to increased diffusion of their work, or other factors. Being the first to freely reveal a particular innovation can also enhance the benefits received, so there can actually be a rush to reveal, much as scientists rush to publish to gain the benefits associated with being the first to have made a particular advancement.

\section{USER INNOVATION COMMUNITIES}

User-innovation efforts tend to be widely distributed. As a result, it's important that user-innovators find ways to combine and leverage their efforts. One way is to engage in many forms of cooperation. Direct, informal user-to-user cooperation (helping others 
to innovate, answering questions, and so on) is common. Organized cooperation is also common, with users joining together in networks and communities that provide useful structures and tools for interacting and for distributing innovations. Such communities can increase the speed and effectiveness with which users-and producers-can develop, test, and disseminate their innovations. Also, they can greatly increase the ease with which innovators can build larger systems from linkable modules created by community participants.

Free and open source software projects are a relatively well-developed, successful form of Internet-based innovation community. They illustrate how users can create, produce, disseminate, provide field support for, update, and use complex products by and for themselves in the context of user-innovation communities. In the case of physical products, the economies of scale associated with manufacturing and distribution often give producers an advantage over "do-it-yourself" users.

However, innovation communities are by no means restricted to software or even to information products; they can play a major role in developing physical products. Indeed, the World Wide Web's rise has enabled vibrant, globally distributed innovation communities with interests in many diverse domains. Furthermore, user-developed products, services, and processes become more valuable to society when disseminated to others who can also benefit from them.

\section{ADAPTING POLICY}

\section{TO USER INNOVATION}

Studies have found that, relative to a world in which only producers innovate, the presence of freely revealed user innovations has probably increased society's welfare. ${ }^{14,15}$ This finding implies that policy making should support user innovation or at least ensure that legislation and regulations do not favor producers at user-innovators' expense.

Research over the past 30 years has convinced many academics that IP law is sometimes (or often) not having its intended effect. IP law was intended to increase the amount of innovation investment. Instead, economies of scope in both patenting and copyright have let firms use these forms of IP law in ways that are directly opposed to policy makers' intent and to the public welfare. Major firms can invest to develop large portfolios of patents and copyrights. They can then use these to create "patent thickets"-dense networks of patent claims that give them plausible grounds for threatening to sue across a wide range of IP and stifle innovation in their areas.

Moreover, users (and producers) tend to build prototypes of their innovations

\section{Policy making should support user innovation or at least ensure that legislation and regulations do not favor producers at user-innovators' expense.}

economically by hacking and modifying products already available on the market to serve a new purpose. Laws such as the US Digital Millennium Copyright Act, intended to prevent consumers from illegally copying protected works, can also have the unintended side effect of preventing users from modifying products that they purchase. Both fairness and social-welfare considerations suggest that innovation-related policies should be made neutral with respect to sources of innovation.

T he ongoing shift of product development from producers to users is painful and difficult for many producers. Open, distributed innovation is "attacking" a major structure of the social division of labor. To adapt, many firms and industries must make fundamental changes to long-held business models. Moreover, social-welfare considerations suggest that the preferential support government sometimes gives to producers who innovate must change. Also, the workings of the IP system are of special concern. But despite these difficulties, a democratized and usercentric system of innovation appears well worth striving for. D

\section{REFERENCES}

1. G.L. Urban and E. von Hippel, "Lead User Analyses for the Development of New Industrial Products," Management Science, vol. 34, no. 5, 1988, pp. 569-582.

2. C. Herstatt and E. von Hippel, "From Experience: Developing New Product Concepts via the Lead User Method: A Case Study in a 'Low Tech' Field," J. Product Innovation Management, vol. 9, no. 3, 1992, pp. 213-222.

3. P.D. Morrison, J.H. Roberts, and E. von Hippel, "Determinants of User Innovation and Innovation Sharing in a Local Market," Management Science, vol. 46, no. 12, 2000, pp. 1513-1527.

4. C. Lüthje, "Customers as Co-Inventors: An Empirical Analysis of the Antecedents of Customer-Driven Innovations in the Field of Medical Equipment," Proc. 32nd European Marketing Academy Conf. (EMAC 03), European Marketing Academy, 2003.

5. N. Franke and E. von Hippel, "Satisfying Heterogeneous User Needs via Innovation Toolkits: The Case of Apache Security Software," Research Policy, vol. 32, no. 7, 2003, pp. 1199-1215.

6. C. Lüthje, "Characteristics of Innovating Users in a Consumer Goods Field: An Empirical Study of Sport-Related Product Consumers," Technovation, vol. 24, no. 9, 2004, pp. 683-695.

7. N. Franke and S. Shah, "How Communities Support Innovative Activities: An Exploration of Assistance and Sharing among End-Users," Research Policy, vol. 32, no. 1, 2003, pp. 157-178.

8. C. Lüthje, C. Herstatt, and E. von Hippel, "The Dominant Role of Local Information in User Innovation: The Case of Mountain Biking," MIT Sloan School of Management working paper no. 4377-02, Massachusetts Inst. of Technology, 2002.

9. E. von Hippel, "Sticky Information and the Locus of Problem Solving: Implications for Innovation," Management Science, vol. 40, no. 4, 1994, pp. 429-439. 
10. S. Ogawa, "Does Sticky Information Affect the Locus of Innovation? Evidence from the Japanese Convenience-Store Industry," Research Policy, vol. 26, nos. 7-8, 1998, pp. 777-790.

11. D. Harhoff, J. Henkel, and E. von Hippel, "Profiting from Voluntary Information Spillovers: How Users Benefit by Freely Revealing Their Innovations," Research Policy, vol. 32, no. 10, 2003, pp. 1753-1769.

12. E. von Hippel, Democratizing Innovation, MIT Press, 2005

13. E. Raymond, The Cathedral and the Bazaar: Musings on Linux and Open Source by an Accidental Revolutionary, O'Reilly, 1999.

14. J. Henkel and E. von Hippel, "Welfare Implications of User Innovation," J. Technology Transfer, vol. 30, nos. 1-2, 2005, pp. 73-87.

15. E. von Hippel and R. Katz, "Shifting Innovation to Users via Toolkits," Management Science, vol. 48, no. 7, 2002, pp. 821-833.

Eric von Hippel is the

T. Wilson Professor of Innovation Management at the MIT Sloan School of Management and a fellow at Harvard Law School's

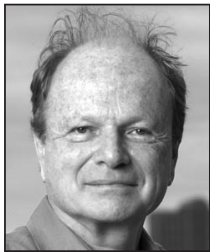
Berkman Center for Inter-

net and Society. If you're interested in a fuller exploration of research findings on user innovation and hacking, please go to http://mit.edu/ evhippel/www/books.htm for a free download of von Hippel's book Democratizing Innovation (MIT Press, 2005). Contact him at evhippel@ mit.edu.

Joseph A. Paradiso is an associate professor at the MIT Media Lab, where he directs the Responsive Environments Group and codirects the Things That Think Consortium. He's an edito-

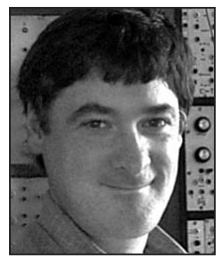
rial board member for IEEE Pervasive Computing. Contact him at joep@media.mit.edu.

\section{Lower nonmember rate of \$29) for S\&P magazine!}

\author{
IEEE Security \& Privacy is \\ THE premier magazine for \\ security professionals.
}

\section{Top security professionals} in the field share information on which you can rely:

- SilverBullet podcasts and interviews

- Intellectual Property Protection and Piracy

- Designing for Infrastructure Security

- Privacy Issues

- Legal Issues and Cybercrime - Digital Rights Management

- The Security Profession

Visit our Web site at www.computer.org/security/

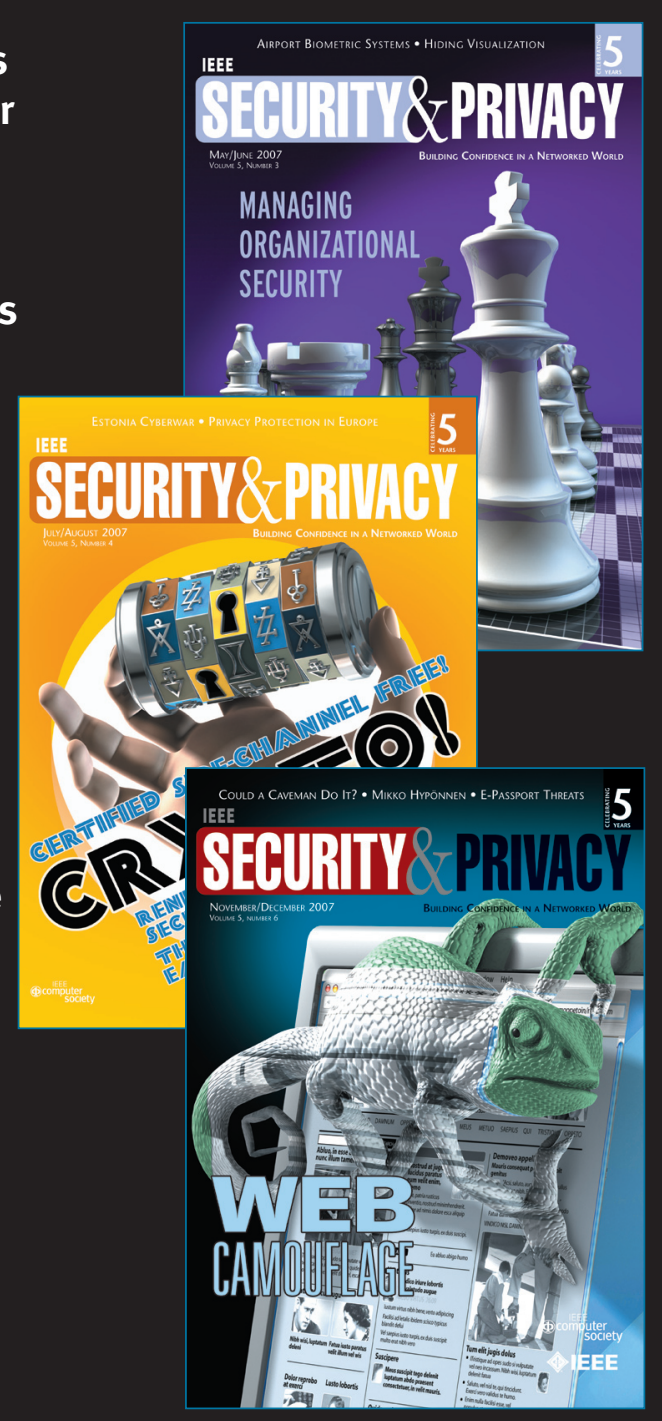

\section{Subscribe now!}

\author{
www.computer.org/services/ \\ nonmem/spbnr
}

